\title{
The Identification of Organic Compounds
}

\author{
VI. Characterisation of Alcohols as p-Bromophenacyl \\ Alkyl Xanthates
}

JøRGEN B ER G ER and INGER ULDALL

\begin{abstract}
Royal Danish School of Pharmacy, Chemical Laboratory B, Copenhagen, Denmark
\end{abstract}
\begin{abstract}
A new type of derivatives for the identification of alcohols is proposed. The alcohol is converted into a $p$-bromophenacyl alkyl xanthate (O-alkyl S-p-bromophenacyl dithiocarbonate). The reaction of the potassium alkyl xanthate with $p$-bromophenacyl bromide proceeds within a few minutes in acetone and no refluxing is required. Isomeric alcohols can be distinguished through these derivatives except for DL-1-phenylethanol/2-phenylethanol and 1-pentanol/3-methyl-1-butanol. These compounds can be identified by their $p$-phenylphenacyl xanthates and by their $p$-chlorophenacyl xanthates, respectively. The melting points of thirty $p$-bromophenacyl alkyl xanthates, four $p$-phenylphenacyl alkyl xanthates and two $p$-chlorophenacyl alkyl xanthates are given.
\end{abstract}

$\mathbf{M}_{1}$

ost primary and secondary alcohols yield the corresponding potassium al$\mathrm{kyl}$ xanthates on treatment with potassium hydroxide and carbon disulphide. The xanthate has for many years been used for the estimation of the equivalent weight of the alcohol in question. The estimation is carried out either by titration with iodine ${ }^{1}$ or by titration with perchloric acid. ${ }^{2}$ In the latter method the xanthate is dissolved in acetic acid in which it immediately decomposes forming an equivalent amount of potassium acetate, alcohol and carbon disulphide. ${ }^{2}$ In glacial acetic acid potassium acetate is a strong base and can be titrated with perchloric acjd.

It has been proposed to use the xanthate not only for quantitative estimation but also for characterisation of alcohols. ${ }^{1}$ However, the melting points of the potassium alkyl xanthates are not very well-defined due to decomposition near the melting point. Antoni and Appel, ${ }^{3}$ therefore, have recommended a determination of the eutectic melting point of a mixture of the xanthate and of dicyandiamide. This method, however, does not permit an unambiguous distinction between the various xanthates.

It is now proposed to prepare $p$-bromophenacyl esters of the xanthic acids (O-alkyl-S-p-bromophenacyl dithiocarbonates):

$$
\mathrm{ROCSSK}+\mathrm{BrC}_{6} \mathrm{H}_{4} \mathrm{COCH}_{2} \mathrm{Br} \rightarrow \mathrm{ROCSSCH}_{2} \mathrm{COC}_{6} \mathrm{H}_{4} \mathrm{Br}+\mathrm{KBr}
$$


The $p$-bromophenacyl alkyl xanthates exhibit well-defined melting points and they are formed simply on addition of $p$-bromophenacyl bromide to a solution of the potassium alkyl xanthate in acetone. The ester is formed within a few minutes and no refluxing is required. Acetone is preferred as the solvent, since most of the potassium alkyl xanthates are soluble in this solvent. Furthermore, potassium bromide is only slightly soluble in acetone and it precipitates during the reaction. The yield of the ester is usually about $90 \%$.

As seen from Table 1 the proposed derivative allows distinction between isomeric alcohols except for DL-1-phenylethanol/2-phenylethanol and 1-pentanol/3-methyl-1-butanol. The $p$-phenylphenacyl xanthates are recommended

Table 1. Corrected capillary melting points and analytical data of some $p$-bromophenacyl alkyl xanthates (O-alkyl S-p-bromophenacyl dithiocarbonates).

\begin{tabular}{|c|c|c|c|c|c|c|}
\hline \multirow{2}{*}{$\begin{array}{l}p \text {-Bromophenacyl ester of } \\
\text { the xanthic acid prepared from }\end{array}$} & \multirow{2}{*}{ M.p. ${ }^{\circ} \mathrm{C}$} & \multirow{2}{*}{ Formula } & \multicolumn{2}{|c|}{$\% \mathrm{C}$} & \multicolumn{2}{|c|}{$\% \mathbf{H}$} \\
\hline & & & calc. & found & calc. & found \\
\hline Methanol & $94-95$ & $\mathrm{C}_{10} \mathrm{H}_{9} \mathrm{BrO}_{2} \mathrm{~S}_{2}$ & 39.34 & 39.48 & 2.97 & 3.01 \\
\hline Ethanol & & $\mathrm{C}_{11} \mathrm{H}_{11} \mathrm{BrO}_{2} \mathrm{~S}_{2}$ & 41.38 & 41.47 & 3.47 & $\mathbf{3 . 3 3}$ \\
\hline 1-Propanol & & $\mathrm{C}_{12} \mathrm{H}_{13} \mathrm{BrO}_{2} \mathrm{~S}_{2}$ & 43.24 & 43.38 & 3.93 & 3.96 \\
\hline 2-Propanol & $90-91$ & $\mathrm{C}_{12} \mathrm{H}_{13} \mathrm{BrO}_{2} \mathrm{~S}_{2}$ & 43.24 & 43.43 & 3.93 & 4.02 \\
\hline 1-Butanol & $\begin{array}{l}65 ; 68 \\
\text { (see text) }\end{array}$ & $\mathrm{C}_{13} \mathrm{H}_{15} \mathrm{BrO}_{2} \mathrm{~S}_{2}$ & 44.94 & 45.01 & 4.35 & 4.50 \\
\hline 2-Butanol & & $\mathrm{C}_{13} \mathrm{H}_{15} \mathrm{BrO}_{2} \mathrm{~S}_{2}$ & 44.94 & 45.15 & 4.35 & 4.26 \\
\hline ropanol & $\begin{array}{c}73 ; 77 ; 85 \\
\text { (see text) }\end{array}$ & $\mathrm{C}_{13} \mathrm{H}_{15} \mathrm{BrO}_{2} \mathrm{~S}_{2}$ & 44.94 & 45.16 & 4.35 & 4.33 \\
\hline 1-Pentanol & $64-65$ & $\mathrm{C}_{14} \mathrm{H}_{17} \mathrm{BrO}_{2} \mathrm{~S}_{2}$ & 46.52 & 46.77 & 4.74 & 4.69 \\
\hline 3-Me & $65-66$ & $\mathrm{C}_{14} \mathrm{H}_{17} \mathrm{BrO}_{2} \mathrm{~S}_{2}$ & 46.52 & 46.69 & 4.74 & 4.56 \\
\hline hyl-1-propanol & 80 & $\mathrm{C}_{14} \mathrm{H}_{17} \mathrm{BrO}_{2} \mathrm{~S}_{2}$ & 46.52 & 46.74 & 4.74 & 4.74 \\
\hline 1-He & $60-61$ & & 47.99 & 48.15 & 5.10 & 5.18 \\
\hline 1-Her & $54-55$ & $\mathrm{C}_{16} \mathrm{H}_{21} \mathrm{BrO}_{2} \mathrm{~S}_{2}$ & 49.35 & 49.36 & 5.44 & 5.49 \\
\hline 1-Oct & $62-63$ & $\mathrm{C}_{17} \mathrm{H}_{23} \mathrm{BrO}_{2} \mathrm{~S}_{2}$ & 50.60 & 50.45 & 5.75 & 5.68 \\
\hline 1-Nonanol & 62 & $\mathrm{C}_{18} \mathrm{H}_{25} \mathrm{BrO}_{2} \mathrm{~S}_{2}$ & 51.80 & 51.82 & 6.04 & 5.90 \\
\hline 1-Dod & 71 & $\mathrm{C}_{21} \mathrm{H}_{31} \mathrm{BrO}_{2} \mathrm{~S}_{2}$ & 54.88 & 55.11 & 6.80 & 6.88 \\
\hline 1-Te & 76 & $\mathrm{C}_{23} \mathrm{H}_{35} \mathrm{BrO}_{2} \mathrm{~S}_{2}$ & 56.65 & 56.89 & 7.24 & 7.43 \\
\hline 1-Hexa & 80 & $\mathrm{C}_{25} \mathrm{H}_{39} \mathrm{BrO}_{2} \mathrm{~S}_{2}$ & 58.24 & 58.35 & 7.63 & 7.60 \\
\hline 2-Pr & 83 & $\mathrm{C}_{12} \mathrm{H}_{11} \mathrm{BrO}_{2} \mathrm{~S}_{2}$ & 43.50 & 43.36 & 3.35 & 3.55 \\
\hline 2-Buten-1-ol & 77 & $\mathrm{C}_{13} \mathrm{H}_{13} \mathrm{BrO}_{2} \mathrm{~S}_{2}$ & 45.21 & 45.45 & 3.80 & 3.94 \\
\hline $2-\mathrm{Me}$ & 55 & $\mathrm{C}_{12} \mathrm{H}_{13} \mathrm{BrO}_{3}$ & 41.26 & 41.43 & 3.75 & 3.73 \\
\hline $2-\mathrm{Et}$ & $\begin{array}{c}53 ; 57 ; 60 \\
\text { (see text) }\end{array}$ & $\mathrm{C}_{13} \mathrm{H}_{15} \mathrm{BrO}_{3} \mathrm{~S}_{2}$ & 42.96 & 43.12 & 4.16 & 4.16 \\
\hline Cyclope & 102 & $\mathrm{C}_{14} \mathrm{H}_{15} \mathrm{BrO}_{2} \mathrm{~S}_{2}$ & 46.79 & 47.01 & 4.21 & 4.47 \\
\hline Сус & 70 & $\mathrm{C}_{15} \mathrm{H}_{1}$ & 48.26 & 48.45 & 4.59 & 4.56 \\
\hline Phenyl & $\begin{array}{l}101 ; 105 \\
\text { (see text) }\end{array}$ & $\mathrm{C}_{16} \mathrm{H}_{13} \mathrm{BrO}_{2} \mathrm{~S}_{2}$ & 50.40 & 50.61 & 3.44 & 3.53 \\
\hline 2-Phenyle & 76 & $\mathrm{C}_{13} \mathrm{H}_{15} \mathrm{BrO}_{2 \mathrm{~K}}$ & 51.64 & 51.82 & 3.83 & 4.05 \\
\hline DL-1-Pr & 79 & $\mathrm{C}_{17} \mathrm{H}_{15} \mathrm{BrO}_{2} \mathrm{~S}_{2}$ & 51.64 & 51.67 & 3.83 & 4.01 \\
\hline 3-Phenyl-1. & 87 & $\mathrm{C}_{18} \mathrm{H}_{17} \mathrm{BrO}_{2} \mathrm{~S}_{2}$ & 52.82 & 52.91 & 4.19 & 4.25 \\
\hline nylmethanol & 112 & $\mathrm{C}_{17} \mathrm{H}_{15} \mathrm{BrO}_{3} \mathrm{~S}_{2}$ & 49.64 & 49.82 & 3.68 & 3.80 \\
\hline Dip & 88 & $\mathrm{C}_{22} \mathrm{H}_{17} \mathrm{BrO}_{2} \mathrm{~S}_{2}$ & 57.76 & 57.86 & 3.75 & 3.91 \\
\hline hanol & $\begin{array}{l}78-79 \\
93-94 \\
\text { (see text) }\end{array}$ & $\mathrm{C}_{14} \mathrm{H}_{15} \mathrm{BrO}_{3} \mathrm{~S}_{2}$ & 44.80 & 45.01 & 4.03 & 4.10 \\
\hline
\end{tabular}


Table 2. Corrected capillary melting points and analytical data of four $p$-phenylphenacyl alkyl xanthates (a) and two $p$-chlorophenacyl alkyl xanthates (b).

\begin{tabular}{|l|l|l|l|l|l|l|}
\hline \multirow{2}{*}{$\begin{array}{c}\text { Subst. phenacyl ester of the } \\
\text { xanthic acid prepared from }\end{array}$} & M.p. ${ }^{\circ} \mathrm{C}$ & Formula & \multicolumn{2}{|c|}{$\% \mathrm{C}$} & \multicolumn{2}{|c|}{$\% \mathrm{H}$} \\
\cline { 5 - 7 } & & & calc. & found & calc. & found \\
\hline & & & & & & \\
DL-1-Phenylethanol (a) & $82-83$ & $\mathrm{C}_{23} \mathrm{H}_{20} \mathrm{O}_{2} \mathrm{~S}_{2}$ & 70.37 & 70.53 & 5.14 & 5.21 \\
2-Phenylethanol (a) & $73-74$ & $\mathrm{C}_{23} \mathrm{H}_{20} \mathrm{O}_{2} \mathrm{~S}_{2}$ & 70.37 & 70.50 & 5.14 & 5.06 \\
1-Pentanol (a) & 54 & $\mathrm{C}_{20} \mathrm{H}_{22} \mathrm{O}_{2} \mathrm{~S}_{2}$ & 67.01 & 67.05 & 6.19 & 6.35 \\
3-Methyl-1-butanol (a) & 57 & $\mathrm{C}_{20} \mathrm{H}_{22} \mathrm{O}_{22} \mathrm{~S}_{2}$ & 67.01 & 67.10 & 6.19 & 6.15 \\
1-Pentanol (b) & 55 & $\mathrm{C}_{14} \mathrm{H}_{17} \mathrm{ClO}_{2} \mathrm{~S}_{2}$ & 53.07 & 53.20 & 5.41 & 5.50 \\
3-Methyl-1-butanol (b) & 64 & $\mathrm{C}_{14} \mathrm{H}_{17} \mathrm{ClO}_{2} \mathrm{~S}_{2}$ & 53.07 & 53.20 & 5.41 & 5.31 \\
\hline
\end{tabular}

for the identification of DL-1-phenylethanol and 2-phenylethanol whereas this derivative cannot be used for the characterisation of the two "amyl" alcohols. The $p$-chlorophenacyl xanthates, however, were found to be well suited for identifying these alcohols. The data are given in Table 2.

Five of the thirty-six derivatives are found to be polymorphous (cf. Experimental). Substituted phenacyl esters have also been extensively used for the identification of carboxylic acids, but polymorphism has never been reported for these derivatives. However, we have recently observed that some of the esters are polymorphous and the discrepancies in the literature can often be explained by this phenomenon. This will be reported in a subsequent paper.

\section{EXPERIMENTAL}

The melting points (corrected) were determined in an electrically heated silicone bath. Rate of heating: $1 \% \mathrm{~min}$. The potassium alkyl xanthates were prepared according to Whitmore and Lieber. ${ }^{1}$ Commercially available alcohols were used. For the preparation of smaller amounts of potassium alkyl xanthates a slightly modified procedure ${ }^{2}$ was followed. The xanthates were recrystallised from acetone or from acetone-ethanol. Their degree of purity was controlled by titration with perchloric acid in glacial acetic acid as a solvent.

General procedure for the preparation of p-bromophenacyl alkyl xanthates. Potassium alkyl xanthate $(0.004$ mole) is dissolved in $10 \mathrm{ml}$ of acetone and $1 \mathrm{ml}$ of water without heating; it may be necessary to add a further $1-2 \mathrm{ml}$ of water in order to get the xanthate completely dissolved. $p$-Bromophenacyl bromide $(1.0 \mathrm{~g}, 0.0036 \mathrm{~mole})$ is dissolved in 10 $\mathrm{ml}$ of acetone. The two solutions are mixed. After standing for $5 \mathrm{~min}$ at room temperature, water $(25-30 \mathrm{ml})$ is added. The mixture is shaken frequently during $5 \mathrm{~min}$ in order to dissolve any potassium bromide. The resulting precipitate is removed by suction and it is recrystallised from ethanol. The melting point of the first crop is in general identical with that of the recrystallised compound. The yield is about $90 \%$.

If no precipitate is formed it may be necessary to cool the solution.

The above procedure can be adjusted to micro or semi-micro scale preparations. Syntheses have been successfully carried out starting with as little as $5 \mathrm{mg}$ of potassium ethyl xanthate.

The $p$-bromophenacyl xanthate of DL-2-pentanol, DL-2-octanol, DL-2-phenyl-1propanol and of cinnamyl alcohol did not crystallise even after standing in a refrigerator. The $p$-bromophenacyl xanthates of crotyl alcohol, DL-1-phenylethanol and of 2-tetrahydrofurylmethanol precipitated as oils which crystallised on standing.

Preparation of p-phenylphenacyl alkyl xanthates and p-chlorophenacyl alkyl xanthates. The substituted phenacyl alkyl xanthates described in Table 2 were prepared according

Acta Chem. Scand. 18 (1964) No. 6 
to the general procedure using $1.0 \mathrm{~g}$ of $p$-phenylphenacyl bromide and $0.85 \mathrm{~g}$ of $p$-chlorophenacyl bromide, respectively. The $p$-phenylphenacyl bromide was dissolved in 20 ml of acetone.

Polymorphism. As indicated in Table 1 some of the derivatives are polymorphous. The low melting forms of the derivatives prepared from isobutyl alcohol, benzyl alcohol and 2-tetrahydrofurylmethanol were obtained by cooling a melted sample.

The derivatives prepared from butyl alcohol and ethyl cellosolve precipitated as the low melting forms. In the determination of the melting point of the two derivatives a nearly clear melt was obtained at the lower temperature and after $2-3$ sec the melt solidified and upon further heating the compound remelted.

The microanalyses have been performed by Mr. A. Bernhardt, Max-Planck-Institut, Mülhoim, Germany.

\section{REFERENCES}

1. Whitmore, W. F. and Lieber, E. Ind. Eng. Chem. Anal. Ed. 7 (1935) 127.

2. Berger, J. Acta Chem. Scand. 6 (1952) 1564.

3. Antoni, W. and Appel, E. Z. Anal. Chem. 143 (1954) 114.

Received May 6, 1964. 